\title{
On the Emulsifying Properties of Self-Assembled Pea Protein Particles
}

\author{
Simha Sridharan, Marcel B. J. Meinders, Johannes H. Bitter, and Constantinos V. Nikiforidis*
}

Cite This: Langmuir 2020, 36, 12221-12229

Read Online

ABSTRACT: Pea proteins are promising oil-in-water emulsifying agents at both neutral and acidic conditions. In an acidic environment, pea proteins associate to form submicrometer-sized particles. Previous studies suggested that the emulsions at acidic $\mathrm{pH}$ were stabilized due to a Pickering mechanism. However, protein particles can be in equilibrium with protein molecules, which could play a significant role in the stabilization of emulsion droplets. Therefore, we revisited the emulsion stabilization mechanism of pea proteins at $\mathrm{pH} 3$ and investigated whether the protein particles or the protein molecules are the major emulsifying agent. The theoretical and experimental surface load of dispersed

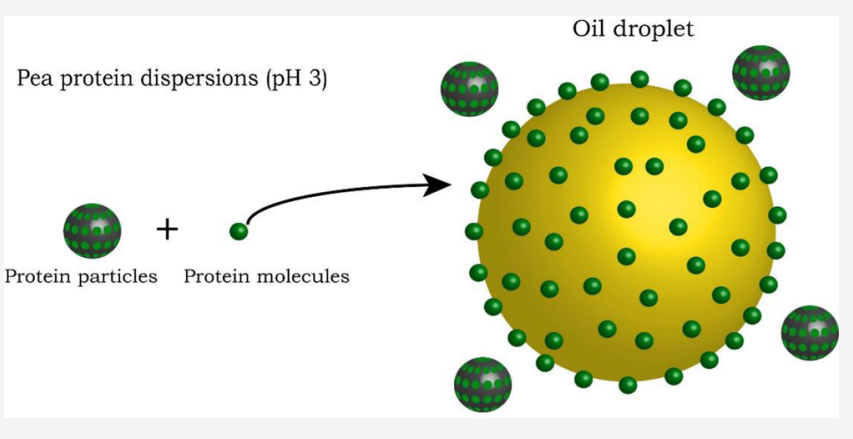
oil droplets were compared, and we found that protein particles can cover only $3.2 \%$ of the total oil droplet surface, which is not enough to stabilize the droplets, whereas protein molecules can cover $47 \%$ of the total oil droplet surface. Moreover, through removing protein particles from the mixture and emulsifying with only protein molecules, the contributions of pea protein molecules to the emulsifying properties of pea proteins at $\mathrm{pH} 3$ were evaluated. The results proved that the protein molecules were the primary stabilizers of the oil droplets at $\mathrm{pH} 3$.

\section{INTRODUCTION}

Proteins are amphiphilic biopolymers that can function as stabilizers of oil-in-water emulsions, as they adsorb on the immiscible oil-water interface and decrease the interfacial tension. ${ }^{1}$ In food applications, dairy and egg proteins are mostly used as emulsifiers; ${ }^{2}$ however, due to environmental concerns, the demand for utilizing plant proteins has tremendously increased. ${ }^{3-6}$ Therefore, several studies have already reported on the emulsifying properties of proteins obtained from plant sources such as soybeans, rapeseed, and peas. $^{6-9}$

Among various plant protein sources, pea proteins have been widely studied in recent years. Peas are mainly composed of carbohydrates and proteins, which enables simpler extraction steps to obtain proteins compared to other oil-rich seeds such as soy and flaxseed that require defatting. ${ }^{10-12}$

Pea proteins extracted by alkaline extraction, mainly a mixture of trimeric $7 \mathrm{~S}$ and hexameric $11 \mathrm{~S}$ globular proteins, have been reported to stabilize oil-water emulsions. ${ }^{13}$ The extracted proteins have their point of zero charge (PZC) at $\mathrm{pH}$ 4.5 , and their emulsifying properties were shown to be different below and above the PZC. ${ }^{14,15}$ Emulsification at acidic $\mathrm{pH}$ with the use of pea proteins resulted in smaller oil droplets than emulsification at neutral $\mathrm{pH} .^{7,14,16}$ Similar behavior has also been reported for other plant proteins such as soy.

The ability of soy and lentil proteins to stabilize smaller oil droplets in an acidic environment was attributed to the dissociation of proteins from their multimeric form into protein subunits (monomers). ${ }^{17}$ These protein monomers have an increased exposed hydrophobicity. ${ }^{18}$ Due to this increased exposed protein, hydrophobicity adsorption of proteins to the droplet surface was promoted. Moreover, due to protein conformational changes at acidic $\mathrm{pH}$, a viscoelastic interface is formed by weak protein-protein interaction. ${ }^{18}$

The dissociation of multimeric proteins (hexameric and trimeric) into monomeric form (protein subunits) is reported in the literature. ${ }^{19}$ However, in relation to an emulsifying mechanism at acidic $\mathrm{pH}$, pea proteins have been reported to self-assemble to form particles. ${ }^{16}$ The fact that the particles are formed even though the proteins are positively charged could be attributed to the enhanced protein-protein physical interactions through hydrophobic and van der Waals forces. ${ }^{20}$ These attractive forces may overcome the electrostatic repulsion leading to protein self-assembly. However, more research on the particle formation mechanism is necessary.

Therefore, the proposed mechanism for emulsification by pea proteins in an acidic environment is that the self-assembled protein particles adsorb on the oil/water surface and stabilize

Received: July 3, 2020

Revised: September 28, 2020

Published: September 28, 2020 
the oil droplets through a Pickering stabilization mechanism. ${ }^{8}$ Pickering emulsions are associated with stable oil droplets stabilized by particles that are irreversibly adsorbed on the droplet surface. ${ }^{21,22}$ The increased droplet stability of Pickering stabilization has attracted great interest in modifying pea proteins to act as Pickering particles in edible emulsion systems, such as by heating to form microgels. ${ }^{23}$ However, a mechanistic study of the emulsifying behavior of alkaline extracted, unmodified pea proteins at $\mathrm{pH} 3$ has not yet been conducted.

The possible coexistence of protein molecules (biopolymer) with protein particles (self-assembled) and their effect on droplet stabilization has not been investigated yet. As has been reported for proteins, and in general for biopolymer selfassemblies, there might be an equilibrium between the number of protein molecules and self-assembled protein particles. ${ }^{24}$ In such cases, a considerable amount of protein molecules may still be present in the pea protein dispersion at $\mathrm{pH} 3$. Owing to the smaller size and faster diffusion of protein molecules compared to protein particles, they would be expected to play a significant role in reducing interfacial tension and in the stabilization of oil droplets. Therefore, the contribution of pea protein molecules to the interfacial properties of pea proteins at $\mathrm{pH} 3$ containing self-assembled particles needs to be evaluated carefully. A pH value of 3 was chosen so as to study the emulsifying behavior of pea proteins in acidic conditions relevant for foods, while avoiding the possibility of acid hydrolysis.

In this research we aimed to understand the emulsifying properties of pea proteins at $\mathrm{pH}$ 3.0. Specifically, we evaluate the possible contribution of protein molecules that could coexist with self-assembled protein particles to droplet stabilization. Interfacial tension reduction and emulsifying properties of pea proteins were investigated. Further, we combined theoretical calculations with experimental techniques to gain critical insights into the emulsifying mechanism of pea proteins containing self-assembled protein particles.

\section{EXPERIMENTAL SECTION}

Materials. Whole yellow field peas (Pisum sativum L.) were obtained from Alimex B.V. (Sint Kruis, The Netherlands). Sodium hydroxide, hydrochloric acid (analytical grade), sodium dodecyl sulfate (SDS) reagent, and fluorescent dyes Nile red and Fast Green were all obtained from Sigma-Aldrich (Zwijndrecht, The Netherlands). Whatman cellulose thimbles were obtained from VWR (Amsterdam, Netherlands).

Purification of Pea Proteins. Pea proteins were extracted from whole yellow peas by alkaline extraction and isoelectric point precipitation, which is commonly reported in the literature. ${ }^{14,18}$ In brief, pea seeds were dry milled into coarse flour in a coffee blender (IKA, Staufen, Germany). The flour was then soaked in water at a $1: 10(\mathrm{w}: \mathrm{w})$ solids to water ratio. The $\mathrm{pH}$ was adjusted to 8 with a 0.5 $\mathrm{M} \mathrm{NaOH}$ solution under constant stirring. After $2 \mathrm{~h}$ of soaking, the slurry was blended in a kitchen blender at maximum speed for $2 \mathrm{~min}$. The resultant slurry was centrifuged at $10000 \mathrm{~g}$ for $30 \mathrm{~min}$ to precipitate solids. Further, the protein-rich supernatant was separated, and the proteins were precipitated at $\mathrm{pH} 4.8$ with a $0.5 \mathrm{M} \mathrm{HCl}$ solution. The solution was allowed to stand for $1 \mathrm{~h}$, and the precipitate was collected by centrifugation at $10000 \mathrm{~g}$ for $30 \mathrm{~min}$. The precipitate was diluted $(1: 10 \mathrm{w} / \mathrm{w})$ with ultrapure water, and the $\mathrm{pH}$ was neutralized $(\mathrm{pH} 7)$. The solution was further freeze-dried, and the obtained powder was termed simply as pea protein. The protein powder was stored in the freezer $\left(-18{ }^{\circ} \mathrm{C}\right)$ for further use.

Composition Analysis. The amount of protein in the extracted pea protein powder was determined with the use of a Dumas nitrogen analyzer (FlashEA 1112 series, Thermo Scientific, Interscience, Breda, The Netherlands). The measurement is based on combusting the sample and analyzing the amount of nitrogen released against a Dmethionine standard. A conversion factor of 6.25 was used. ${ }^{25}$

$$
\text { protein content }(\mathrm{wt} \%)=\frac{\text { nitrogen content } \times 6.25}{\text { initial sample dry mass }} \times 100
$$

The ash content in the samples was determined by drying a known mass ( $1 \mathrm{~g}$ ) of sample in a calcination oven (P330, Nabertherm $\mathrm{GmbH}$, Lilienthal, Germany) at $550{ }^{\circ} \mathrm{C}$ for $24 \mathrm{~h}$ and the weight percent ash was calculated as follows.

$$
\operatorname{ash}(\text { wt } \%)=\frac{\text { final sample mass }}{\text { initial dry sample mass }} \times 100
$$

The amount of oil present in extracted pea protein powder was determined by a solvent extraction process. A known amount of dry sample was added to cellulose thimbles. Empty round-bottom flasks were weighed and filled with hexane. The thimbles were fitted into the extraction unit, and the round-bottom flask with hexane was evaporated $\left(60{ }^{\circ} \mathrm{C}\right)$ and used to extract the oil for $6 \mathrm{~h}$. Afterward, the round-bottom flask containing oil and hexane was removed and hexane was evaporated under a fume hood for 6 days. The solventfree extract in the round-bottom flask was weighed. The amount of oil present was directly determined from the increase of weight in the round-bottom flask after solvent evaporation.

$$
\text { oil content }(w t \%)=\frac{\text { flask weight after extraction }- \text { empty flask weight }}{\text { sample weight }} \times 100
$$

Oil-in-Water Emulsion Preparation. Oil-in-water emulsions were prepared with pea protein dispersions used as aqueous phase. Dispersions of 10.0 wt \% rapeseed oil and $90.0 \mathrm{wt} \%$ protein were used. The final protein content of the emulsion was standardized to $0.5 \mathrm{wt} \%$ by adjustment of the protein content in the dispersion. The $\mathrm{pH}$ of the dispersion was changed to $\mathrm{pH} 3$ with the use of $0.5 \mathrm{M} \mathrm{HCl}$. The dispersion was then stirred for $3 \mathrm{~h}$ under magnetic stirring. The dispersion was then sheared for $15 \mathrm{~s}$ at $6000 \mathrm{rpm}$ in an IKA (UltraTurrax, IKA, Staufen, Germany) Ultra-Turrax to ensure homogeneous dispersion of proteins. Further, rapeseed oil was added slowly, and the mixture was sheared for another $60 \mathrm{~s}$ at $10000 \mathrm{rpm}$ to produce a coarse emulsion. The formed coarse emulsion was further homogenized by passing through a GEA (Niro Soavi NS $1001 \mathrm{~L}$, Parma, Italy) high pressure homogenizer for five passes at a homogenization pressure of $250 \mathrm{bar}$. The obtained final emulsion was allowed to equilibrate $3 \mathrm{~h}$ before any measurement was performed. The emulsions were called pea protein stabilized emulsions and were made in duplicate.

Emulsions were also prepared with the use of protein molecule solution (supernatant after centrifugation). In brief, pea protein dispersions were prepared as explained above. Then the dispersion was ultracentrifugated at $320000 \mathrm{~g}$ for $45 \mathrm{~min}$ at $20{ }^{\circ} \mathrm{C}$ with a Beckman-Coulter L60 (Beckmann-Coulter Nederland B.V, Woerden, The Netherlands) ultracentrifuge in $40 \mathrm{~mL}$ glass tubes. The clear supernatants were carefully collected by pouring them into a beaker. The collected solution was called protein molecule solution. Emulsions were prepared as described above with this solution.

Protein Dispersion Size and Charge. The hydrodynamic size of the particles in the protein dispersion was measured at $\mathrm{pH} 3$ with the use of a Malvern UltraSizer (Malvern Instruments Ltd., Malvern, U.K.). In brief, protein dispersions of 0.5 wt $\%$ were prepared as explained in the previous section and homogenized without addition of oil. The homogenized protein dispersion was loaded into a disposable clear cuvette, the size was measured with a refractive index of 1.45 , and a temperature of $20^{\circ} \mathrm{C}$ was set. Similarly, the protein molecule solution size was measured under the same conditions.

Surface charges of proteins of the same dispersions were measured with a U-shaped cuvette in the Malvern Ultra Sizer (Malvern Instruments Ltd., Malvern, U.K.) at $20{ }^{\circ} \mathrm{C}$. All size and charge 
measurements were done after $120 \mathrm{~s}$ of equilibration and were performed in triplicate, and the average value was reported.

Droplet Size Measurement. The individual droplet size of the emulsions was measured with laser diffraction in a Malvern Mastersizer 3000 (Malvern Instruments Ltd., Malvern, U.K.). The samples were dispensed with a hydrodispenser, and the droplet size was represented by the volume mean diameter.

To measure individual droplet sizes, the emulsions were treated with 1 wt \% SDS solution. Addition of SDS breaks droplet aggregation driven by protein interaction, so the size of individual oil droplets could be measured in this manner. ${ }^{26}$ Equal volumes (1 $\mathrm{mL}$ ) of emulsion and $1 \mathrm{wt} \%$ SDS solution were mixed, and the size was immediately measured with the use of a refractive index of 1.47 . Similarly, the droplet size distribution of the emulsions was determined after 7 days of storage at $4{ }^{\circ} \mathrm{C}$ to assess the coalescence stability.

Measured Protein Surface Coverage of Oil Droplets. The amount of protein covering the oil droplet surface was measured and reported in milligrams per square meter. The experimental surface coverage was measured according to our earlier work. ${ }^{27}$ In brief, the emulsion samples were centrifuged at $10000 \mathrm{~g}$ for $30 \mathrm{~min}$ at $4{ }^{\circ} \mathrm{C}$. The cream layer was then collected by removing the serum layer from the centrifuge tube by puncturing a hole at the bottom of the tube. The cream was dispersed in ultrapure water $(1: 10(\mathrm{w}: \mathrm{w})$ cream to water). The dispersion was centrifuged again at $3000 \mathrm{~g}$ for $15 \mathrm{~min}$ at $4{ }^{\circ} \mathrm{C}$. The second washed cream layer was also collected similarly to the first centrifugation and dried. The amount of protein in the cream layer was measured with the use of a Dumas nitrogen analyzer as explained under Composition Analysis.

The protein surface load $\left(\Gamma_{s}\right)$ was roughly estimated by use of the equation $^{28}$

$$
\Gamma_{\mathrm{s}}=\frac{\Gamma_{\mathrm{T}}}{S_{\mathrm{T}}}
$$

where $\Gamma_{\mathrm{T}}$ is the total measured protein content in the cream layer and $S_{\mathrm{T}}$ is the total surface area.

$$
S_{\mathrm{T}}=\frac{6}{D_{(3,2)}} V_{\text {oil }}
$$

where $V_{\text {oil }}$ is the volume of oil and $D_{(3,2)}$ is the surface mean diameter obtained from laser diffraction experiments.

Theoretical Estimation of Protein Surface Coverage of Oil Droplets. The measured surface load of the emulsions was compared with the theoretically estimated surface load. The theoretical surface load of protein molecules and protein particles can be calculated by use of eq $6 .^{29}$ (For more details on the mathematical considerations to derive the formula, the reader is referred to the Supporting Information.)

$$
\Gamma=\frac{4}{3} \rho_{\mathrm{p}} \varphi_{\max } r_{\mathrm{p}} \quad\left(\mathrm{mg} / \mathrm{m}^{2}\right)
$$

where $\rho_{\mathrm{p}}$ is $1.37 \mathrm{~g} / \mathrm{cm}^{3}, \varphi_{\max }$ is 0.91 for circles packed on a flat surface with the assumption that the droplet surface is a two-dimensional entity, and $r_{\mathrm{p}}$ is the radius of the protein/particle.

Two scenarios were considered for theoretical estimation of the surface load. The first was assuming that the interface was covered by protein particles, whose radius was based on the hydrodynamic size obtained from size measurement. The second scenario was assuming that the interface was solely covered by protein molecules. The radius of a protein molecule was estimated based on its molecular weight according to the following equation. ${ }^{23}$

$$
r_{\mathrm{p}}=0.066 \mathrm{M}^{1 / 3} \quad(\mathrm{~nm})
$$

where $M$ is molecular weight of the protein in daltons.

The following assumptions were taken into consideration for calculating the theoretical surface load:

1. Equal amounts of legumin (11S) and vicilin (7S) proteins were present at the droplet surface. Therefore, an average size between that of legumin, $4.69 \mathrm{~nm}$, and that of vicilin, $3.50 \mathrm{~nm}$, was used to calculate the theoretical radius of the protein. ${ }^{30}$ (For more details on the protein molecule size, please refer to the Supporting Information.)

2. The density of both protein molecules and protein particles was assumed to be $1.37 \mathrm{~g} / \mathrm{cm}^{3}$.

3. The proteins are circles on a two-dimensional droplet surface.

Interfacial Tension and Dilatational Moduli. The interfacial tension reduction and dilatational rheology of the oil-pea protein dispersion interface and the oil-protein molecule solution interface were measured with an automated drop tensiometer (Tracker, Teclis Instruments, Tassin, France). A 0.01 wt $\%$ pea protein and corresponding pea protein molecule solution $(0.01 \mathrm{wt} \%$ protein dispersion after centrifuged) were prepared as explained under Oil-inWater Emulsion Preparation.

Rapeseed oil was treated with Florisil overnight to remove impurities and was used as the oil phase. In brief a $1: 3(\mathrm{w} / \mathrm{w})$ ratio of Florisil to oil was mixed overnight and centrifuged the next day to obtain contaminant-free oil, which was used in the interfacial study.

In the drop tensiometer, the rapeseed oil was loaded onto a $500 \mu \mathrm{L}$ syringe fitted with a J-shaped needle. The aqueous phase was filled into a clean, $7 \mathrm{~mL}$ optical glass cuvette. The needle was inserted into the aqueous phase, and a sessile drop of $15 \mathrm{~mm}^{2}$ area was made. The shape of the oil droplet was monitored continuously with a camera. This was converted into interfacial tension by the Wdrop software from Teclis Instruments (Tassin, France). The dynamic interfacial tension reduction profile was monitored continuously for $3.5 \mathrm{~h}$ and plotted against time in a semilog plot. The interfacial tension reduction was modeled with the use of a curve-fitting procedure using the equation ${ }^{31}$

$$
\gamma_{t}=\gamma_{\infty}+\gamma_{1} \mathrm{e}^{-t / t_{1}}+\gamma_{1} \mathrm{e}^{-t / t_{2}}
$$

where $\gamma_{t}$ is the interfacial tension at a given time, $\gamma_{\infty}$ is the final interfacial tension, and $\gamma_{1}$ and $\gamma_{2}$ are fitting constants. $t$ is the time in seconds; $t_{1}$ is the time in seconds, related to the lag phase; and $t_{2}$ is the time in seconds, related to the rearrangement phase.

After $3.5 \mathrm{~h}$ of measurement of the interfacial tension, dilatational viscoelasticity was measured by changing the surface area of the droplet in a sinusoidal manner. The droplet was subjected to changes in surface area with amplitudes of 5 and $10 \%$ up to $30 \%$ deformation with respect to the initial surface area $\left(15 \mathrm{~mm}^{2}\right)$. Each amplitude was applied for $100 \mathrm{~s}$ with five cycles next to each other. This was followed by $500 \mathrm{~s}$ of rest period before the next higher amplitude was applied. The interfacial tension change and change in area were recorded during the oscillation, and the dilatational elastic $\left(E_{\mathrm{d}}{ }^{\prime}\right)$ and viscous moduli $\left(E_{\mathrm{d}}{ }^{\prime \prime}\right)$ were obtained.

Light Microscopy and Confocal Microscopy (CLSM). Emulsions were visualized with the use of light microscopy (Axioscope, Zeiss, Jena, Germany) using $100 \times$ magnification, with a 5 times dilution in ultrapure water. The images were captured with an Axiovert digital camera (Zeiss, Jena, Germany) and Axiovision imaging software (Zeiss, Jena, Germany).

The emulsions were imaged with the use of a confocal laser scanning microscope (CLSM) with the aid of fluorescent dyes to visualize the microstructure. In brief, about $1 \mathrm{~mL}$ of emulsion was mixed with $7 \mu \mathrm{L}$ of Nile red and $7 \mu \mathrm{L}$ of Fast green FCF in an Eppendorf tube. The tubes were sealed and allowed to mix for $15 \mathrm{~min}$. Afterward, about $30 \mu \mathrm{L}$ of sample was deposited on a microscopy slide and mounted on the confocal table. A Leica SP8 confocal microscope fitted with a $63 \times$ water immersion lens and white light laser was used to image the samples. Nile red stained the oil phase and was excited at $488 \mathrm{~nm}$, and the emission was captured between 500 and $600 \mathrm{~nm}$. Rhodamine B, which stained proteins, was excited at 566 $\mathrm{nm}$, and the emission was captured between 570 and $670 \mathrm{~nm}$. The images were captured in a sequential manner with Leica imaging software.

Transmission Electron Microscopy. The emulsions were imaged with TEM after the sample was fixated on polymer resin. Briefly, the emulsions were mixed together $1: 1(\mathrm{v} / \mathrm{v})$ with $3 \mathrm{wt} \%$ agarose solution at $40{ }^{\circ} \mathrm{C}$. Then the mixture was allowed to solidify in 

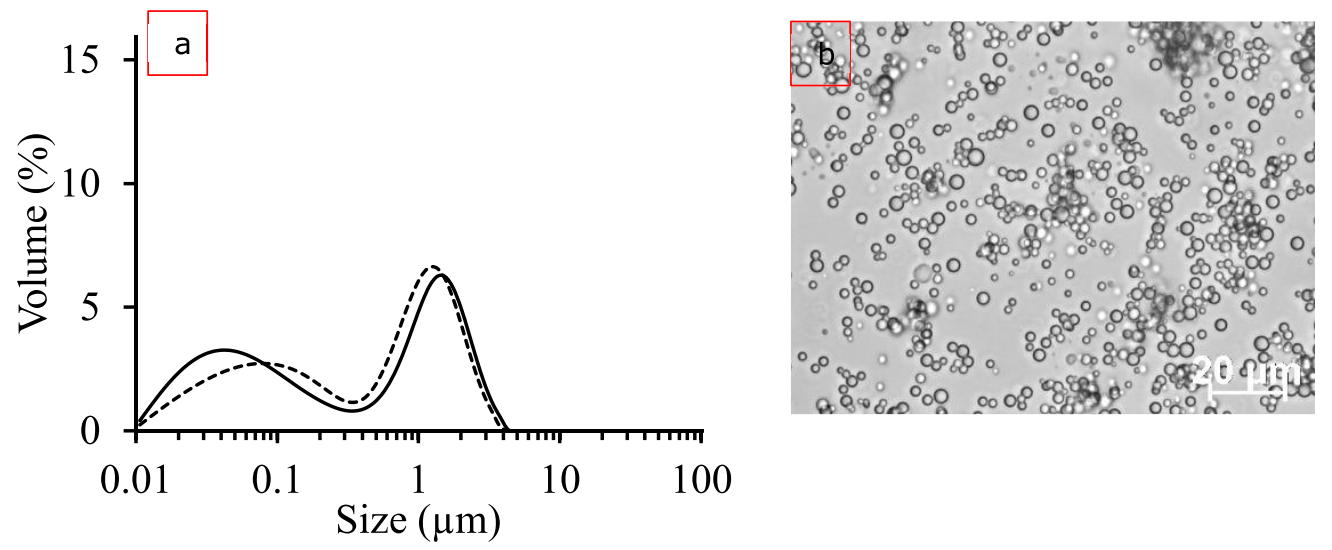

Figure 1. (a) Particle size distribution of $10.0 \mathrm{wt} \%$ oil-in-water emulsion freshly prepared (solid line) and after 7 days of storage at $4{ }^{\circ} \mathrm{C}($ dashed line) stabilized with the use of $0.5 \mathrm{wt} \%$ protein, pea protein extract. (b) Light micrograph of the emulsion shown (scale bar $20 \mu \mathrm{m} /$ diluted 5 times).

the refrigerator at $4{ }^{\circ} \mathrm{C}$. The hardened tubes were cut into $1 \mathrm{~mm} \times 1$ $\mathrm{mm}$ cubes. The cubes were then fixed with glutaraldehyde for $1 \mathrm{~h}$ and then washed with $0.1 \mathrm{M}$ phosphate buffer three times. The cubes were subsequently fixated with $1 \%$ osmium tetroxide and washed with ultrapure water. Then dehydration protocol was started by ethanol washing. A series of $30,50,70,80 \%$, and up to $100 \%$ ethanol washing steps were performed each lasting for $30 \mathrm{~min}$. After the last ethanol wash, the samples were mixed with Spurr's embedding liquid in three steps of 2:1,1:1, and 1:2 (ethanol:Spurr's) with each step being 30 min long. After this, the samples were left in $100 \%$ Spurr's for $1 \mathrm{~h}$ and refreshed with $100 \%$ Spurr's again and left overnight. The following day, Spurr's was refreshed again for $1 \mathrm{~h}$ and then the sample was left to polymerize for $8 \mathrm{~h}$ at $70{ }^{\circ} \mathrm{C}$. The Spurr's polymerized and the samples were embedded in it. Next, the samples were sectioned with the use of Leica EM rapid (Leica Biosystems, Nussloch, Germany). Afterward, the samples were more precisely sectioned by the use of a Leica ultramicrotome UC7 into $70 \mathrm{~nm}$ thin slices. The slices were collected with Formvar film 150 mesh copper TEM grids. The grids containing the samples were loaded into a Jeol JEM1400 plus- $120 \mathrm{kV}$ TEM (Jeol B.V., Nieuw-Vennep, The Netherlands) with an EM11210 SQCH specimen quick change holder. The samples were imaged at $120 \mathrm{kV}$. The protein particles after homogenization were also viewed with the TEM. The protein particle dispersion was placed on a copper grid. The samples were stained with $2 \mu \mathrm{L}$ of phosphotungstic acid (PTA) for $15 \mathrm{~s}$. Then the samples were dried with fiberless filter paper pieces and washed once with water and dried again. The dried copper grid was then transferred onto a Jeol JEM2100 TEM chamber and imaged.

\section{RESULTS AND DISCUSSION}

The composition of the extracted pea proteins was 84 wt \% protein, $6 \mathrm{wt} \%$ oil, and $3 \mathrm{wt} \%$ ash, similar to the already reported compositions of pea protein extracts. ${ }^{15,32}$ The proteins were characterized for their surface charge density (zeta $(\zeta)$ potential) and solubility as a function of $\mathrm{pH}$ (Figure S1). The $\zeta$ potential and solubility curves shown were similar to what has been reported for pea proteins, with the point of zero charge of $\mathrm{pH} 4.6$ and minimum solubility between $\mathrm{pH} 4$ and $5 .^{15,33}$

To further evaluate the emulsifying property of pea proteins, oil-in-water emulsions were prepared at $\mathrm{pH}$ 3.0. The particle size distribution of the resulting emulsion is shown in Figure $1 \mathrm{a}$, and the corresponding light micrograph of the emulsion is shown in Figure 1b. Figure la shows droplet size distributions for fresh emulsions and after storage for 7 days. The light micrograph shows oil droplets in fresh emulsions that contained spherical droplets. The size distribution curve shows a bimodal size distribution with a clear distinction between the two peaks. The hypothesis is that the oil droplets correspond to the curve in the size range between 0.5 and 5 $\mu \mathrm{m}$. The smaller submicrometer peak between 0.01 and 0.7 $\mu \mathrm{m}$ could be related to protein particles. ${ }^{16}$

After storage for 7 days, no significant change in the droplet size distribution was observed (Figure 1a, dashed line), indicating that the amount of protein present at the droplet surface was sufficient to avoid droplet coalescence.

The size distribution curve between 0.01 and $0.50 \mu \mathrm{m}$ observed in Figure 1a could correspond to the pea protein particles. ${ }^{16}$ To investigate the cause of the submicrometer peak, the protein dispersion was homogenized at the same conditions as the emulsions, but without addition of the oil. The particle size of the homogenized dispersion is given in Figure 2. Figure 2 shows a monomodal particle size

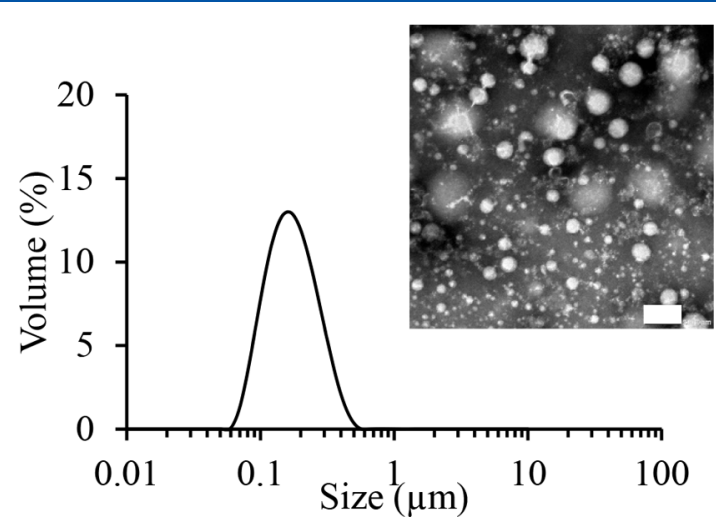

Figure 2. Size distribution self-assembled protein particles at $\mathrm{pH} 3$, homogenized at 250 bar pressures. (inset) TEM image of protein particles ( 0.5 wt \% protein; scale bar $200 \mathrm{~nm}$ ).

distribution curve in the submicrometer range. The inset in Figure 2 shows a representative transmission electron micrograph of the homogenized protein particle dispersion with spherical particles in light gray. The size distribution shows that particles in the size range between 0.05 and $0.70 \mu \mathrm{m}$ with a peak around $0.12 \mu \mathrm{m}$ were observed. According to the literature, this peak could be attributed to self-assembled protein particles present in positively charged pea protein dispersion. ${ }^{16}$ Moreover, spherical particles observed in the TEM correspond well with the size distribution and are most 
likely protein particles since the extracted protein powder used here contains about $85 \mathrm{wt} \%$ protein. The presence of protein particles at $\mathrm{pH} 3$ despite being below the isoelectric point shows that the driving force for the formation of the protein particles could be a combination of physical forces such as hydrophobic and van der Waals forces that overcome the electrostatic repulsion.

The protein particles of sizes 0.05 and $0.70 \mu \mathrm{m}$ (Figure 2) formed at $\mathrm{pH} 3.0$ have been attributed as the droplet stabilizing agent in pea proteins through a Pickering stabilization mechanism. ${ }^{8,16,34}$ To investigate whether the protein particles were adsorbed on the oil droplet surface, confocal and electron microscopic analyses were employed (Figure 3). The confocal micrograph (Figure 3a) shows oil

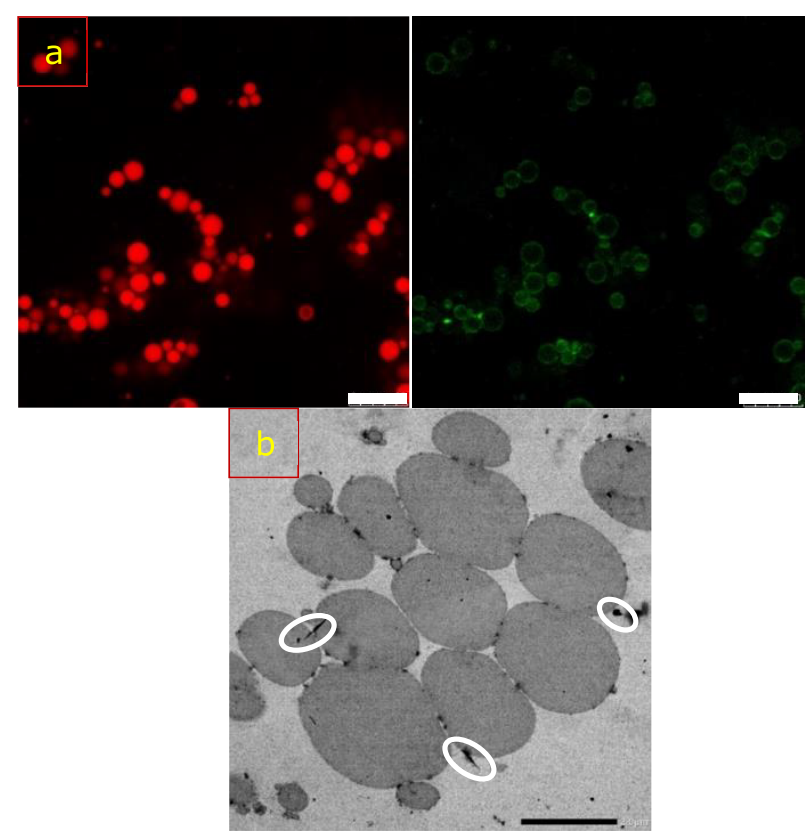

Figure 3. (a) Confocal micrograph showing oil droplets in red and protein surrounding the oil droplets in green (scale bar $10 \mu \mathrm{m}$ ). (b) TEM micrograph of emulsion droplets with protein particles encircled (scale bar $2 \mu \mathrm{m}$ ); $10.0 \mathrm{wt} \%$ oil-in-water emulsion stabilized by $0.5 \mathrm{wt}$ $\%$ pea proteins at $\mathrm{pH} 3.0$.

droplets (red) surrounded by proteins (green). Figure 3a shows that the protein particles were only found in patches at the droplet surface and were not seen as a homogeneous layer around the oil droplets. In addition, not all the oil droplets were covered by the protein particles. To gain a more detailed visualization of the droplet surface, transmission electron microscopy analysis was employed (Figure $3 b$ ), which shows oil droplets in gray and proteins in black. The image shows a clear interface of oil droplets covered with denser regions, which are proteins. Also, the protein particles are not covering the entire droplet surface, similar to the observation from the confocal micrograph.

From the microscopic analysis, it was not clear whether solely protein particles were stabilizing the oil droplet surface. Therefore, more information on the state of the proteins adsorbed was required to understand the emulsifying mechanism. Therefore, the surface coverage (mass of protein per unit surface area) of the formed oil droplets was calculated theoretically (using eq 6) and compared with the experimentally measured surface coverage.
The positively charged pea proteins self-assemble to form particles; however, since only physical forces such as van der Waals forces and hydrophobic forces drive the particle formation, an equilibrium between protein molecules and protein particles might exist. ${ }^{20,24}$ Therefore, two scenarios were considered when calculating the theoretical surface load. The first one is based on a droplet surface stabilized by protein particles of $60 \mathrm{~nm}$ radius, which was obtained from the particle size analysis of homogenized pea protein dispersion, where the peak particle size is around $120 \mathrm{~nm}$ (peak value from Figure 2). The second scenario is based on a droplet surface stabilized by protein molecules of $4.1 \mathrm{~nm}$ radius, which was calculated from the molecular weight of the protein molecules according to eq 7. The two theoretical scenarios were compared with experimentally measured surface load as shown in Figure 4.

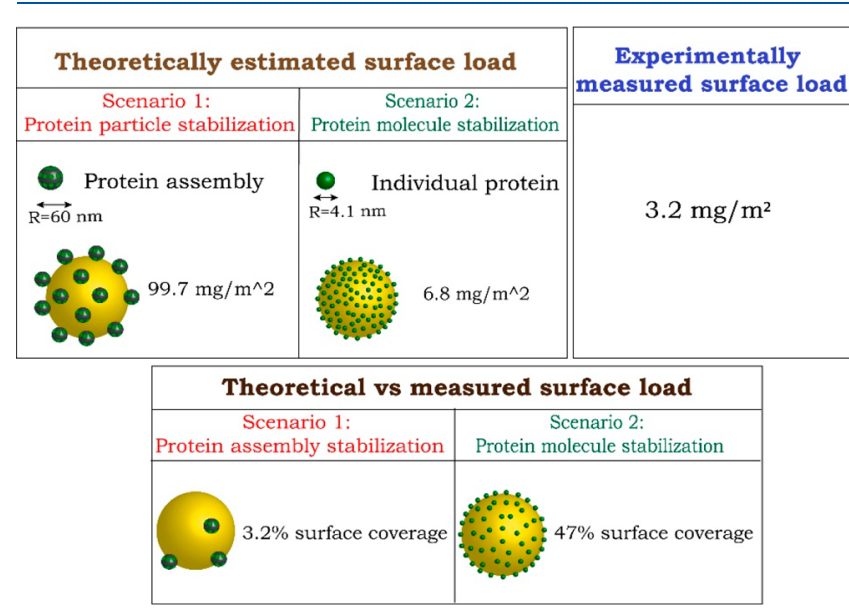

Figure 4. Comparison between measured surface load and theoretical surface load based on two scenarios: (1) protein particle stabilization (radius $r_{\mathrm{p}}=60 \mathrm{~nm}$, obtained from Figure 2); (2) protein molecule stabilization (radius $r_{\mathrm{p}}=4.1 \mathrm{~nm}$ ), of $10.0 \mathrm{wt} \%$ oil-in-water emulsion stabilized by pea proteins.

Figure 4 shows the theoretical surface load based on the two scenarios (top left) and the experimentally measured surface load (top right). The bottom part of Figure 4 shows the comparison between the theoretical and experimental surface loads for the two scenarios.

Considering the theoretical scenario that protein particles of $60 \mathrm{~nm}$ radius are adsorbed on the droplet surface, eq 6 suggests that $99.7 \mathrm{mg} / \mathrm{m}^{2}$ protein particles would be needed for complete surface coverage. In the theoretical scenario where protein molecules adsorbed on the surface, $6.82 \mathrm{mg} / \mathrm{m}^{2}$ protein molecules would be needed for complete surface coverage. The experimentally measured surface load of the emulsion oil droplets was only $3.2 \mathrm{mg} / \mathrm{m}^{2}$ (eq 4). Moreover, when the measured and theoretical surface loads are compared, for protein particle stabilized surface, the surface coverage was $3.21 \%$ of the theoretical coverage. However, in the scenario where protein molecules stabilize the droplet surface, the fraction of surface covered was $46.94 \%$ of the theoretical coverage.

Studies have shown that model spherical particles can stabilize oil droplets by covering as little as $10-20 \%$ of the oil droplet surface. ${ }^{35}$ However, in cases of protein particles such as soy glycinin, a coverage of $40 \%$ or higher was reported. Similarly, when whey protein nanogels were used, surface coverage of $68 \%$ was found to critical. ${ }^{36,37}$ Therefore, the 
estimated surface coverage of $3.2 \%$ for Pickering stabilization for pea protein stabilized emulsion would not be sufficient to stabilize the oil droplets and avoid further coalescence. ${ }^{38,39}$ Moreover, studies have shown that the surface load for protein Pickering particles was between 20 and $25 \mathrm{mg} / \mathrm{m}^{2}$, which is lower than what we have estimated theoretically but much higher than the measured surface load in this research. ${ }^{36}$ The comparison indicates that it is possible that the second scenario takes place; that is, protein molecules are adsorbed on the droplet surface.

To confirm the hypothesis that protein molecules were also present in the pea proteins at $\mathrm{pH} 3$, the protein dispersion was centrifuged at an ultrahigh rotation speed. The supernatant after ultracentrifugation contained about 40 wt $\%$ of the proteins present in the initial dispersion (measured by the Lowry method of S3 protein solubility). The size distribution of the resultant supernatant shows a monomodal distribution between 3 and $20 \mathrm{~nm}$ (Figure 5). Figure 5 clearly shows the

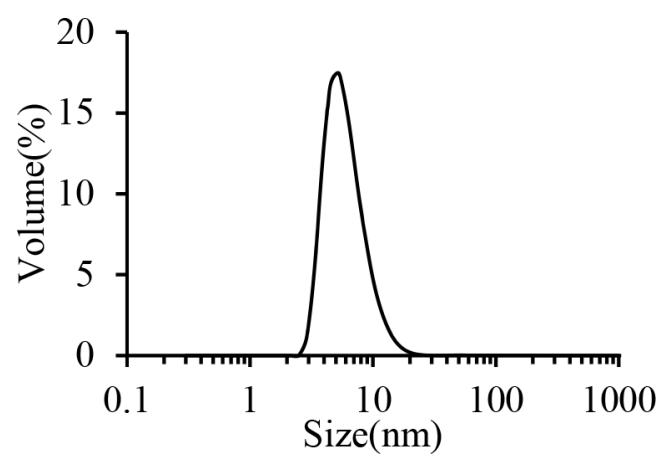

Figure 5. Particle size distribution of protein molecule solution obtained after centrifugation of $0.5 \mathrm{wt} \%$ pea protein dispersion at $\mathrm{pH}$ 3.0.

presence of smaller proteins compared to the protein particles seen before homogenization. Moreover, the size distribution seen here corresponds well with the theoretical protein molecule size of $\sim 8.2 \mathrm{~nm}$ (4.1 nm radius). Moreover, the size distribution shown here corresponds well with what has been experimentally reported for pea protein molecules of legumin and vicilin $\left(r_{\mathrm{g}} \sim 4.5 \mathrm{~nm}\right)$ and for protein assembly of three to six oligomers $\left(r_{\mathrm{g}} \sim 25 \mathrm{~nm}\right)$. $^{40-42}$

The presence of protein molecules $(3-20 \mathrm{~nm})$ showed that the pea proteins coexisted as particles and as protein molecules in the pea protein dispersion at $\mathrm{pH} 3$ with an equilibrium between them. Therefore, pea proteins at $\mathrm{pH} 3$ can be described as a protein particle-molecule mixture. The fraction of protein particles and protein molecules in our case was 60:40 (wt:wt) respectively (measured by Lowry). The existence of protein molecules implies that a minimum protein concentration is required for self-assembly to occur. The concentration dependency for protein assembly indicates that the particle formation was diffusion controlled and was driven by reversible physical forces. ${ }^{24}$
An important requirement of the interfacially active molecules, such as proteins, is their ability to adsorb onto the oil-water surface and reduce the interfacial tension. Therefore, the pea protein particle-molecule mixture was compared with the protein molecule solution for their interfacial tension reducing property. The shape of the tension reduction curve consisted of a lag phase and an adsorption phase which is characteristic for protein adsorption at the droplet surface. ${ }^{31}$ During the lag phase, protein molecules do not sufficiently cover the droplet interface and there is no interaction between them at the interface, leading to a lack of interfacial tension reduction. ${ }^{43}$ Such a lag phase may not exist in a real emulsion system due to the much higher concentration of proteins used. During the second phase (adsorption phase), proteins adsorb and rearrange at the droplet surface, which leads to a noticeable reduction in interfacial tension. ${ }^{30}$

The tension curves were fit to an exponential equation (eq 8 ), and the results are summarized in Table 1. Table 1 shows that, for both systems, the interfacial tension decreased over $3.5 \mathrm{~h}$ from around $25 \mathrm{mN} / \mathrm{m}$ to around $14 \mathrm{mN} / \mathrm{m}$. Moreover, the lag time $\left(t_{1} \sim 150 \mathrm{~s}\right)$ was much lower than the rearrangement time $\left(t_{2} \sim 3000 \mathrm{~s}\right)$ for both systems. This indicated that, after the lag time, a period of gradual reduction in interfacial tension was associated with interfacial rearrangement of proteins. The slow rearrangement has also been shown in the literature for pea globulins at acidic conditions. ${ }^{44}$ The slow decline has been attributed to the structural reorganization of pea globulins hexamers (and trimers) into their monomeric subunits. Similar tension reduction profiles for both protein particle-molecule mixture and the protein molecule systems indicated that the interfacial tension reducing property of pea protein dispersion mainly comes from the protein molecules and not from the protein particles.

The viscoelastic properties of the film formed at the droplet surface give information on the interactions between the molecules adsorbed at the droplet surface. Therefore, interfacial dilatational experiments were performed and the resulting dilatational elastic $\left(E_{\mathrm{d}}{ }^{\prime}\right)$ and viscous moduli $\left(E_{\mathrm{d}}{ }^{\prime \prime}\right)$ of pea protein particle-molecule mixture and pea protein molecules are shown in Figure 6. The dilatational elastic modulus $\left(E_{\mathrm{d}}{ }^{\prime}\right)$ was observed to be higher than the viscous modulus $\left(E_{\mathrm{d}}{ }^{\prime \prime}\right)$ over the range of amplitude tested for both systems. The $E_{\mathrm{d}}{ }^{\prime}$ curves of the protein particle-molecule mixture and the protein molecule solution follow each other closely. Therefore, it can be concluded that protein molecules in the protein particle-molecule mixture mainly adhere to the droplet surface and form a cohesive network.

Moreover, the modulus curves did not show a large amplitude dependency over the tested range, indicating that the protein-protein interactions at the droplet surface led to the formation of a cohesive network that remained intact under the applied surface area changes. The protein network was probably formed by physical interactions, which overcame the electrostatic repulsion. The protein network can prevent the

Table 1. Interfacial Tension Parameters of Pea Protein Particle-Molecule Mixture and Pea Protein Molecule Solution Measured Using Drop Tensiometer for $12000 \mathrm{~s}$ at $20^{\circ} \mathrm{C}$

\begin{tabular}{lcccc}
\hline sample & initial tension $(\mathrm{mN} / \mathrm{m})$ & lag time $\left(t_{1}\right)(\mathrm{s})$ & rearrangement time $\left(t_{2}\right)(\mathrm{s})$ & final tension after $12000 \mathrm{~s}(\mathrm{mN} / \mathrm{m})$ \\
\hline protein particle-molecule mixture & 24.7 & 154 & 3137 & 13.41 \\
protein molecule solution & 23.2 & 121 & 2845 & 14.49
\end{tabular}




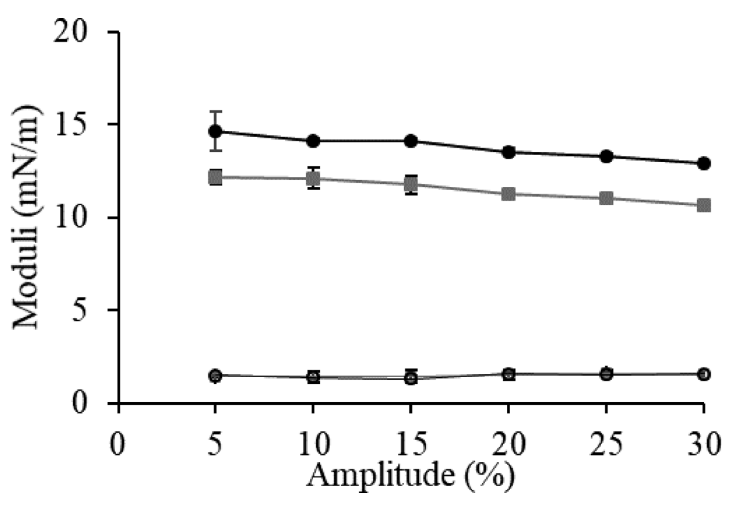

Figure 6. Dilatational elastic (filled) and viscous moduli (unfilled) of pea protein particle-molecule mixture (black) and pea protein molecule solution (gray) measured after $3.5 \mathrm{~h}$ of steady interfacial tension decrease as a function of amplitude of deformation.

rupture of droplet surface and subsequent destabilization of the droplet. $^{45}$

To further confirm that protein molecules were the major stabilizers of the oil droplets in the pea protein particlemolecule mixture, emulsions were prepared using the protein supernatant obtained after ultracentrifugation. The same initial protein concentration was used for ultracentrifugation compared to what was used to prepare pea protein emulsion (Figure 1). The droplet size distribution of the resulting emulsion is shown in Figure 7a for fresh emulsions (solid line) and after 7 days (dashed line). The distribution curve is monomodal with size between $500 \mathrm{~nm}$ and $5 \mu \mathrm{m}$. The inset in Figure $7 \mathrm{a}$ shows a light micrograph of the formed emulsion in the fresh state. The droplet size distribution of the formed emulsion was stable over storage for 7 days, indicating no coalescence (Figure 7a). Moreover, the droplet size distribution of the protein molecules stabilized emulsion corresponded well with that of the emulsions made with the pea protein particle-molecule mixture (Figure 1a). The light micrograph (Figure 7, inset) also showed that the droplets were spherical and showed a similar microstructure compared to that of pea protein particle-molecule emulsion (Figure 1b).

To investigate the microstructure of the emulsion, confocal analysis (Figure 7c) and TEM analysis (Figure 7b) were employed. The confocal micrograph shows oil droplets (red) and proteins (in green), while the TEM micrograph (Figure $7 \mathrm{~b})$ shows oil droplets in gray and darker patches of proteins. The confocal micrograph (Figure $7 \mathrm{c}$ ) showed that the formed oil droplets appeared with a homogeneous interface and no dense protein areas could be observed. The homogeneous droplet interface without protein particles was also confirmed from the electron micrograph (Figure $7 \mathrm{~b}$ ). Also, the electron micrograph clearly shows that the droplet surface of the protein molecules stabilized emulsion was identical to that of the pea protein particle-molecule emulsion (Figure $3 b$ ). The similarity between the droplet surfaces of the two emulsions indicated that protein molecules in the pea protein particlemolecule mixture were responsible for the droplet surface stabilization. These findings clearly show that the protein particles do not play a major role in the droplet surface stabilization of pea proteins at $\mathrm{pH}$ 3.0.

\section{CONCLUSIONS}

In this work we investigated the interfacial and emulsifying properties of pea proteins at $\mathrm{pH}$ 3.0. We showed that pea proteins self-assembled to form particles of size between 0.05 and $0.7 \mu \mathrm{m}$. Most of the proteins were not present as particles, since $40 \mathrm{wt} \%$ of the total protein in the protein particle-
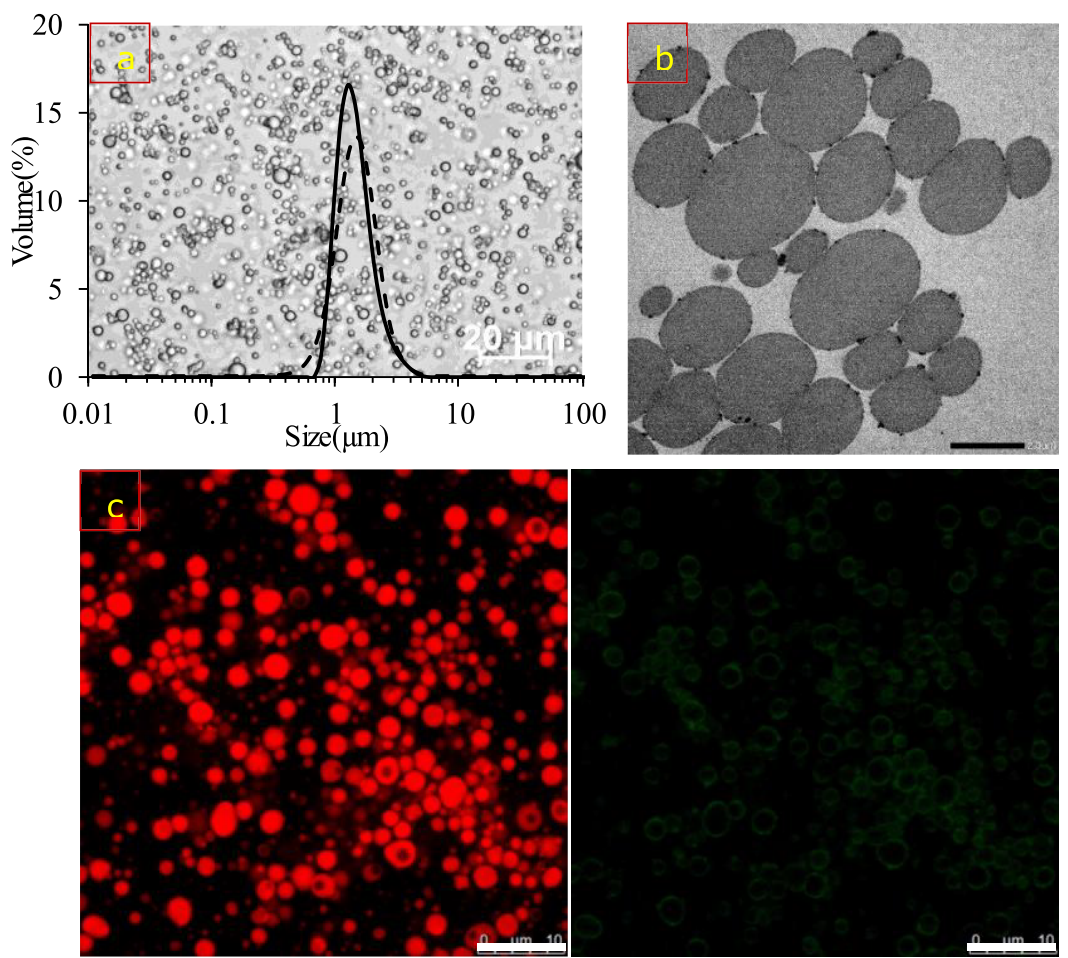

Figure 7. (a) Droplet size distribution of emulsion prepared with protein molecule solution: day 0 (solid line) and day 7 (dashed line). (inset) Light micrograph of the emulsion at day 0 (scale bar $20 \mu \mathrm{m} /$ diluted 5 times). (b) TEM image of emulsion stabilized with protein molecules (scale bar $2 \mu \mathrm{m}$ ). (c) Confocal micrograph of emulsion prepared with protein molecules at day 0 (oil, red; protein, green; scale bar $10 \mu \mathrm{m}$ ). 
molecule mixture existed as protein molecules. The size distribution of the protein molecules (Figure 7) was between 3 and $20 \mathrm{~nm}$ in accordance with the calculated size of pea globulins and with what has been reported in the literature for globular plant proteins at $\mathrm{pH} 3 .^{18}$ The protein particlemolecule mixture reduced the interfacial tension and formed stable oil-in-water emulsions. The measured surface load of the emulsion was compared with the theoretical surface load. The comparison showed that, when protein particles would stabilize the surface, only $3.2 \%$ of the droplet surface would be covered. On the other hand, when protein molecules would stabilize the surface, $47 \%$ of the droplet surface would be covered. Therefore, protein molecules are more likely the major stabilizing agent. To verify that protein molecules were responsible for stabilization, the emulsion was prepared with protein molecules. The resulting emulsion was stable against coalescence and showed a similar droplet size compared to that of the emulsion stabilized with the protein particle-molecule mixture. Therefore, we concluded that the mechanism of emulsification in pea proteins at $\mathrm{pH} 3.0$ is not based on protein particles but is based on protein molecules. In addition, we show that, when studying the emulsifying properties of protein aggregates/particles, the presence of protein molecules should not be neglected.

\section{ASSOCIATED CONTENT}

\section{SI Supporting Information}

The Supporting Information is available free of charge at https://pubs.acs.org/doi/10.1021/acs.langmuir.0c01955.

Equations for theoretical surface load estimation, equations for legumin and vicilin size estimation, theoretical sizes of legumin and vicilin molecules, pea protein solubility and $\zeta$ potential as a function of $\mathrm{pH}$ (PDF)

\section{AUTHOR INFORMATION}

\section{Corresponding Author}

Constantinos V. Nikiforidis - Biobased Chemistry and Technology (BCT), Wageningen University and Research, 6708 WG Wageningen, The Netherlands; 이이. orcido000-00027231-4805; Phone: +31(0)317488042;

Email: costas.nikiforidis@wur.nl

\section{Authors}

Simha Sridharan - Biobased Chemistry and Technology (BCT), Wageningen University and Research, 6708 WG Wageningen, The Netherlands; TiFN, 6709 PA Wageningen, The Netherlands

Marcel B. J. Meinders - Wageningen Food and Biobased Research (FBR), 6708 WG Wageningen, The Netherlands

Johannes H. Bitter - Biobased Chemistry and Technology (BCT), Wageningen University and Research, 6708 WG Wageningen, The Netherlands

Complete contact information is available at: https://pubs.acs.org/10.1021/acs.langmuir.0c01955

\section{Author Contributions}

S.S., conceptualization, execution, and writing-original manuscript; M.B.J.M., conceptualization, writing-review, and editing; J.H.B., writing-review and editing; C.V.N., conceptualization, supervision, writing-review, and editing.

\section{Notes}

The authors declare no competing financial interest.

\section{ACKNOWLEDGMENTS}

The authors would like to thank Irene van den Hoek, Helene Mocking-Bode, and Harry Baptist for their help with laboratory experiments. The research was conducted under the auspices of TiFN, a public-private partnership on precompetitive research in the areas of food and nutrition. The fund was provided by Danone Nutricia research B.V., Fromageries Bel S.A, PepsiCo Inc., and Unilever R\&D B.V.

\section{REFERENCES}

(1) Lam, R. S. H.; Nickerson, M. T. Food Proteins: A Review on Their Emulsifying Properties Using a Structure-Function Approach. Food Chem. 2013, 141 (2), 975-984.

(2) Ozturk, B.; McClements, D. J. Progress in Natural Emulsifiers for Utilization in Food Emulsions. Curr. Opin. Food Sci. 2016, 7, 1-6.

(3) Pimentel, D.; Pimentel, M. Sustainability of Meat-Based and Plant-Based Diets and the Environment. Am. J. Clin. Nutr. 2003, 78 (3), 660S-663S.

(4) Berghout, J. A. M.; Pelgrom, P. J. M.; Schutyser, M. A. I.; Boom, R. M.; Van Der Goot, A. J. Sustainability Assessment of Oilseed Fractionation Processes: A Case Study on Lupin Seeds. J. Food Eng. 2015, 150, 117-124.

(5) Pelgrom, P. J. M.; Boom, R. M.; Schutyser, M. A. I. Functional Analysis of Mildly Refined Fractions from Yellow Pea. Food Hydrocolloids 2015, 44, 12.

(6) Poore, J.; Nemecek, T. Reducing Food 's Environmental Impacts through Producers and Consumers. Science (Washington, DC, U. S.) 2018, 360 (6392), 987-992.

(7) Sharif, H. R.; Williams, P. A.; Sharif, M. K.; Abbas, S.; Majeed, H.; Masamba, K. G.; Safdar, W.; Zhong, F. Current Progress in the Utilization of Native and Modified Legume Proteins as Emulsifiers and Encapsulants - A Review. Food Hydrocolloids 2018, 76, 2-16.

(8) Burger, T. G.; Zhang, Y. Recent Progress in the Utilization of Pea Protein as an Emulsifier for Food Applications. Trends Food Sci. Technol. 2019, 86, 25-33.

(9) Ntone, E.; Bitter, J. H.; Nikiforidis, C. V. Not Sequentially but Simultaneously: Facile Extraction of Proteins and Oleosomes from Oilseeds. Food Hydrocolloids 2020, 102, 105598.

(10) Nikbakht Nasrabadi, M.; Goli, S. A. H.; Sedaghat Doost, A.; Roman, B.; Dewettinck, K.; Stevens, C. V.; Van der Meeren, P. Plant Based Pickering Stabilization of Emulsions Using Soluble Flaxseed Protein and Mucilage Nano-Assemblies. Colloids Surf., A 2019, 563, 170-182.

(11) Nikbakht Nasrabadi, M.; Goli, S. A. H.; Sedaghat Doost, A.; Dewettinck, K.; Van der Meeren, P. Bioparticles of Flaxseed Protein and Mucilage Enhance the Physical and Oxidative Stability of Flaxseed Oil Emulsions as a Potential Natural Alternative for Synthetic Surfactants. Colloids Surf., B 2019, 184, 110489.

(12) Molina Ortiz, S. E.; Wagner, J. R. Hydrolysates of Native and Modified Soy Protein Isolates: Structural Characteristics, Solubility and Foaming Properties. Food Res. Int. 2002, 35 (6), 511-518.

(13) Karaca, A. C.; Low, N.; Nickerson, M. Emulsifying Properties of Chickpea, Faba Bean, Lentil and Pea Proteins Produced by Isoelectric Precipitation and Salt Extraction. Food Res. Int. 2011, 44 (9), 2742-2750.

(14) Liang, H. N.; Tang, C. H. PH-Dependent Emulsifying Properties of Pea [Pisum Sativum (L.)] Proteins. Food Hydrocolloids 2013, 33 (2), 309-319.

(15) Lam, A. C. Y.; Can Karaca, A.; Tyler, R. T.; Nickerson, M. T. Pea Protein Isolates: Structure, Extraction, and Functionality. Food Rev. Int. 2018, 34 (2), 126-147.

(16) Liang, H.; Tang, C. Pea Protein Exhibits a Novel Pickering Stabilization for Oil-in-Water Emulsions at PH 3.0. LWT - Food Sci. Technol. 2014, 58 (2), 463-469. 
(17) Chang, C.; Tu, S.; Ghosh, S.; Nickerson, M. T. Effect of PH on the Inter-Relationships between the Physicochemical, Interfacial and Emulsifying Properties for Pea, Soy, Lentil and Canola Protein Isolates. Food Res. Int. 2015, 77, 360-367.

(18) Jarpa-Parra, M.; Bamdad, F.; Tian, Z.; Zeng, H.; Temelli, F.; Chen, L. Impact of PH on Molecular Structure and Surface Properties of Lentil Legumin-like Protein and Its Application as Foam Stabilizer. Colloids Surf., B 2015, 132, 45-53.

(19) Gueguen, J.; Chevalier, M.; And, J. B.; Schaeffer, F. Dissociation and Aggregation of Pea Legumin Induced by $\mathrm{PH}$ and Ionic Strength. J. Sci. Food Agric. 1988, 44 (2), 167-182.

(20) Roth, C. M.; Neal, B. L.; Lenhoff, A. M. Van Der Waals Interactions Involving Proteins. Biophys. J. 1996, 70, 977-987.

(21) Sarkar, A.; Dickinson, E. Sustainable Food Grade Pickering Emulsions Stabilized by Plant-Based Particles. Curr. Opin. Colloid Interface Sci. 2020, 49, 69-81.

(22) Tang, C. H. Globular Proteins as Soft Particles for Stabilizing Emulsions: Concepts and Strategies. Food Hydrocolloids 2020, 103, 105664.

(23) Zhang, S.; Holmes, M.; Ettelaie, R.; Sarkar, A. Pea Protein Microgel Particles as Pickering Stabilisers of Oil-in-Water Emulsions: Responsiveness to $\mathrm{PH}$ and Ionic Strength. Food Hydrocolloids 2020, 102, 105583.

(24) Amin, S.; Barnett, G. V.; Pathak, J. A.; Roberts, C. J.; Sarangapani, P. S. Protein Aggregation, Particle Formation, Characterization \& Rheology. Curr. Opin. Colloid Interface Sci. 2014, 19 (5), 438-449.

(25) Taherian, A. R.; Mondor, M.; Labranche, J.; Drolet, H.; Ippersiel, D.; Lamarche, F. Comparative Study of Functional Properties of Commercial and Membrane Processed Yellow Pea Protein Isolates. Food Res. Int. 2011, 44 (8), 2505-2514.

(26) Tangsuphoom, N.; Coupland, J. N. Effect of Surface-Active Stabilizers on the Microstructure and Stability of Coconut Milk Emulsions. Food Hydrocolloids 2008, 22 (7), 1233-1242.

(27) Sridharan, S.; Meinders, M. B. J.; Bitter, J. H.; Nikiforidis, C. V. Native Pea Flour as Stabilizer of Oil-in-Water Emulsions: No Protein Purification Necessary. Food Hydrocolloids 2020, 101, 105533.

(28) Diftis, N.; Kiosseoglou, V. Competitive Adsorption between a Dry-Heated Soy Protein-Dextran Mixture and Surface-Active Materials in Oil-in-Water Emulsions. Food Hydrocolloids 2004, 18 (4), 639-646.

(29) Rayner, M.; Marku, D.; Eriksson, M.; Sjöö, M.; Dejmek, P.; Wahlgren, M. Biomass-Based Particles for the Formulation of Pickering Type Emulsions in Food and Topical Applications. Colloids Surf., A 2014, 458 (1), 48-62.

(30) Erickson, H. P. Size and Shape of Protein Molecules at the Nanometer Level Determined by Sedimentation, Gel Filtration, and Electron Microscopy. Biol. Proced. Online 2009, 11 (1), 32-51.

(31) Nikiforidis, C. V.; Ampatzidis, C.; Lalou, S.; Scholten, E.; Karapantsios, T. D.; Kiosseoglou, V. Purified Oleosins at Air-Water Interfaces. Soft Matter 2013, 9, 1354-1363.

(32) Boye, J. I.; Aksay, S.; Roufik, S.; Ribéreau, S.; Mondor, M.; Farnworth, E.; Rajamohamed, S. H. Comparison of the Functional Properties of Pea, Chickpea and Lentil Protein Concentrates Processed Using Ultrafiltration and Isoelectric Precipitation Techniques. Food Res. Int. 2010, 43, 537.

(33) Boye, J.; Zare, F.; Pletch, A. Pulse Proteins: Processing, Characterization, Functional Properties and Applications in Food and Feed. Food Res. Int. 2010, 43 (2), 414-431.

(34) Xiao, J.; Li, Y.; Huang, Q. Recent Advances on Food-Grade Particles Stabilized Pickering Emulsions: Fabrication, Characterization and Research Trends. Trends Food Sci. Technol. 2016, 55, 48-60.

(35) Midmore, B. Low Surface Coverage-Colloids and Surfaces -Synthetic Particles.Pdf. Colloids Surf., A 1998, 132, 257-265.

(36) Destribats, M.; Rouvet, M.; Gehin-Delval, C.; Schmitt, C.; Binks, B. P. Emulsions Stabilised by Whey Protein Microgel Particles: Towards Food-Grade Pickering Emulsions. Soft Matter 2014, 10 (36), 6941-6954.
(37) Araiza-Calahorra, A.; Sarkar, A. Pickering Emulsion Stabilized by Protein Nanogel Particles for Delivery of Curcumin: Effects of PH and Ionic Strength on Curcumin Retention. Food Structure 2019, 21, 100113.

(38) Destribats, M.; Lapeyre, V.; Wolfs, M.; Sellier, E.; LealCalderon, F.; Ravaine, V.; Schmitt, V. Soft Microgels as Pickering Emulsion Stabilisers: Role of Particle Deformability. Soft Matter 2011, 7 (17), 7689-7698.

(39) Dickinson, E. Biopolymer-Based Particles as Stabilizing Agents for Emulsions and Foams. Food Hydrocolloids 2017, 68, 219-231.

(40) I’Anson, K. J.; Miles, M. J.; Bacon, J. R.; Carr, H. J.; Lambert, N.; Morris, V. J.; Wright, D. J. Structure of the 7S Globulin (Vicilin) from Pea (Pisum Sativum). Int. J. Biol. Macromol. 1988, 10 (5), 311317.

(41) Plietz, P.; Zirwer, D.; Schlesier, B.; Gast, K.; Damaschun, G. Shape, Symmetry, Hydration and Secondary Structure of the Legumin from Vicia Faba in Solution. Biochim. Biophys. Acta, Protein Struct. Mol. Enzymol. 1984, 784 (2-3), 140-146.

(42) Adal, E.; Sadeghpour, A.; Connell, S.; Rappolt, M.; Ibanoglu, E.; Sarkar, A. Heteroprotein Complex Formation of Bovine Lactoferrin and Pea Protein Isolate: A Multiscale Structural Analysis. Biomacromolecules 2017, 18 (2), 625-635.

(43) Tsoukala, A.; Papalamprou, E.; Makri, E.; Doxastakis, G.; Braudo, E. E. Adsorption at the Air-Water Interface and Emulsification Properties of Grain Legume Protein Derivatives from Pea and Broad Bean. Colloids Surf., B 2006, 53 (2), 203-208.

(44) Gharsallaoui, A.; Cases, E.; Chambin, O.; Saurel, R. Interfacial and Emulsifying Characteristics of Acid-Treated Pea Protein. Food Biophys. 2009, 4 (4), 273-280.

(45) Tenorio, A. T.; De Jong, E. W. M.; Nikiforidis, C. V.; Boom, R. M.; Van Der Goot, A. J. Interfacial Properties and Emulsification Performance of Thylakoid Membrane Fragments. Soft Matter 2017, 13 (3), 608-618. 